\title{
Ordovician Chitinozoa and biostratigraphy from Skåne and Bornholm, southernmost Scandinavia - an overview and update
}

\author{
YNGVE GRAHN \& JAAK NÕLVAK
}

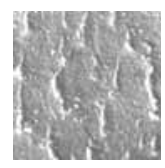

\begin{abstract}
Ordovician chitinozoans from Skåne (Sweden) and Bornholm (Denmark), in southernmost Scandinavia, are discussed. Previously published information on Ordovician chitinozoans from these two provinces is reviewed and complemented with new data. Characteristic Baltoscandian chitinozoan faunas have been found from the uppermost Tremadocian (H. copiosus Zone) to the Ordovician-Silurian boundary interval. Besides the uppermost Tremadocian strata, the Lower Ordovician part of the Tøyen Formation (Floian to lowermost Darriwilian) has not been investigated. The Belonechitina micracantha-robusta-wesenbergensis complex is discussed in some detail. The forty-nine species, of which twelve in open nomenclature, are from fifteen genera. One species, Conochitina scabra n. sp., from the uppermost Lindegård Mudstone and lower Tommarp Formation (uppermost Katian-lower Hirnantian) in Skåne, is newly described. • Key words: Ordovician, Chitinozoa, Scandinavia, Skåne, Bornholm.
\end{abstract}

GRAHN, Y. \& NÕLVAK, J. 2007. Ordovician Chitinozoa and biostratigraphy from Skåne and Bornholm, southernmost Scandinavia - an overview and update. Bulletin of Geosciences 82(1), 11-26 (11 figures). Czech Geological Survey, Prague. ISSN 1214-1119. Manuscript received May 22, 2006; accepted in revised version November 29, 2006; issued March 30, 2007. • DOI 10.3140/bull.geosci.2007.01.11

Yngve Grahn, Universidade do Estado do Rio de Janeiro, Faculdade de Geologia, Bloco A - Sala 4001, Rua São Francisco Xavier 524, 20550-013 Rio de Janeiro, R.J., Brazil; yngvegrahn@hotmail.com•Jaak Nõlvak, Tallinn University of Technology, Institute of Geology, Ehitajate tee 5, 19086 Tallinn, Estonia; nolvak@gi.ee

Skåne (Sweden) and Bornholm (Denmark) comprise the southernmost Ordovician outcrop areas in Scandinavia. Ordovician chitinozoans from Skåne have earlier been discussed (or mentioned) by J. Bergström et al. (1968), S.M. Bergström et al. (1997, 2000), Eisenack (1968, p. 186), Grahn (1978, 1980, p. 34), Lindström (1953), Nilsson (1960, 1977), Nõlvak \& Grahn (1993, p. 247), Schallreuter (1981, 1983), and Vandenbroucke (2004). S.M. Bergström \& Nilsson (1974, p. 31) and Laufeld (1967, p. 281) have mentioned Ordovician chitinozoans from Bornholm. The present study reviews and updates upper Tremadocian to Hirnantian chitinozoans from these two regions. The sample size is, in general, $50 \mathrm{~g}$. The chronostratigraphy follows that of Ogg (2004).

\section{Geological setting}

Skåne and Bornholm are situated along the Tornquist Line, on the southwestern margin of the Baltic Shield; and towards the Wendean Basin (Jaanusson 1976). Ordovician rocks are present as a series of outliers along this border zone (Fig. 1). Scandinavia can be divided into three confa- cies belts (sensu Jaanusson 1995) during the Ordovician, viz. the Oslo belts, Scanian Lithofacies belt and the Central Baltoscandian Confacies belt. The Scanian Lithofacies belt is predominantly developed in a graptolitic facies along the margin of the Baltic Shield; whereas the other two confacies belts are dominated by carbonate facies with shelly fossils (Fig. 1). The Scanian Lithofacies belt includes Ordovician rocks of Bornholm, Skåne and the western part of Västergötland (Halleberg-Hunneberg district). In the Early-Middle Ordovician, at least until the lowermost Darriwilian (upper Arenig), this lithofacies belt reached into the Oslo Region (Lindholm 1991, Jaanusson 1995).

\section{Skåne}

Skåne, the southernmost province of Sweden, is situated on the southwestern margin of the Baltic Shield. Palaeozoic rocks occur in a belt stretching SE-NW. Ordovician rocks are restricted to fault blocks, concentrated to six areas, i.e. SE Skåne, Fågelsång, Albjära, Rävatofta, Röstånga, and NW Skåne (Fig. 2). The lithologies are predominantly graptolitic shales and mudstones; and only three limestone 


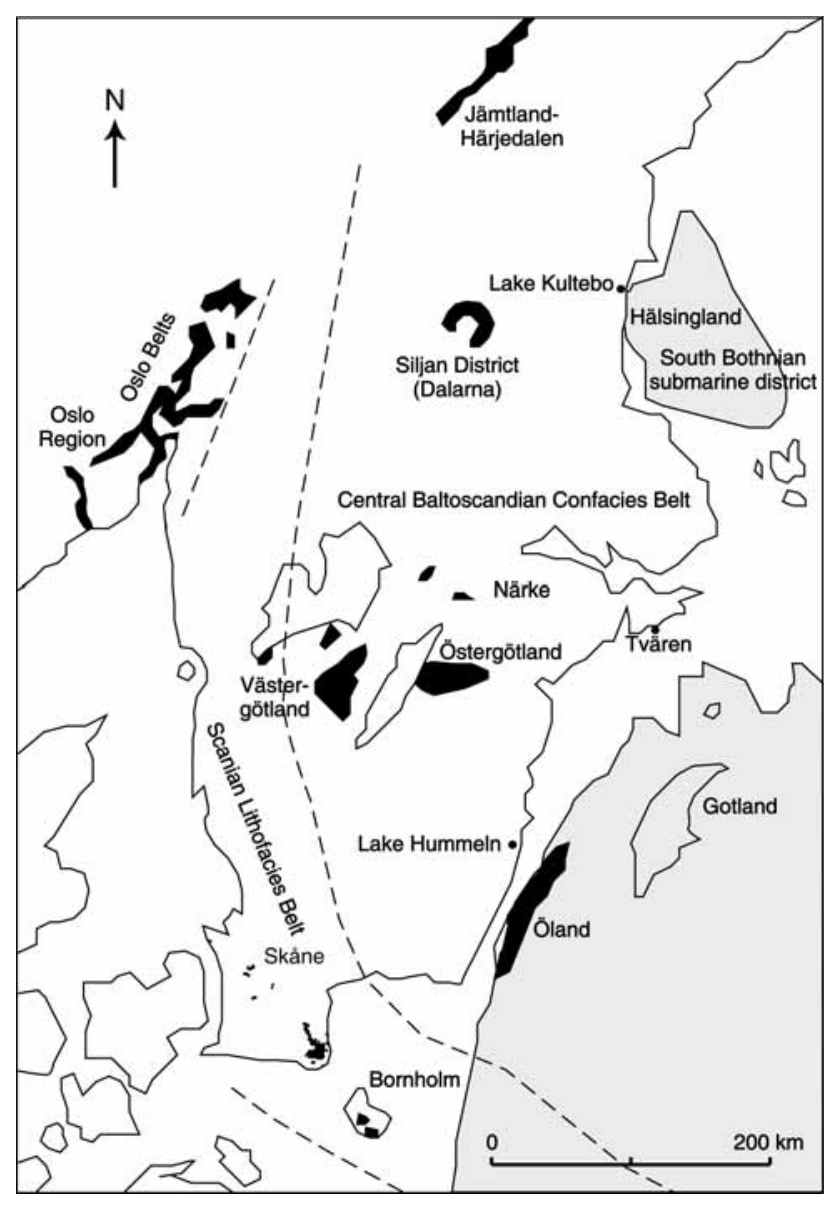

Figure 1. Map showing extent of Ordovician rocks and confacies belts (sensu Jaanusson 1995) in Scandinavia. Black color shows Ordovician outcrop areas, and grey color is submarine occurrencies of Ordovician rocks.

levels of significance in the Ordovician are known, i.e. Björkåsholmen Formation, Komstad Limestone, and Skagen Formation. The total thickness of the Ordovician is about $200 \mathrm{~m}$. The re-visited localities are described below in stratigraphic order.

Krapperup core (loc. 1 on Fig. 2). - This well was drilled by Wargön AB in 1946, and is located on the beach about $950 \mathrm{~m} \mathrm{~W}$ of Krapperup Castle, and about $500 \mathrm{~m}$ NNW of the village of Lerhamn. The hole penetrated Ordovician rocks to a total depth of $155.06 \mathrm{~m}$. One sample at $150.50 \mathrm{~m}$, in the Hunnegraptus copiosus Zone (uppermost Tremadocian), yielded Lagenochitina esthonica, a long-ranging Tremadocian to early Darriwilian species. Graptolites from this core have been described by Lindholm (1991).

Lovisefred core (loc. 3 on Fig. 2). - This well was drilled by TGB for the Geological Survey of Sweden in 1977, and is located about $1 \mathrm{~km} \mathrm{~S}$ of Lovisefred Farm, and about $4 \mathrm{~km}$ NNE of Höganäs church. The core penetrates Early Silurian to Stage 3 (Arenig; D. hirundo Zone) strata to a total

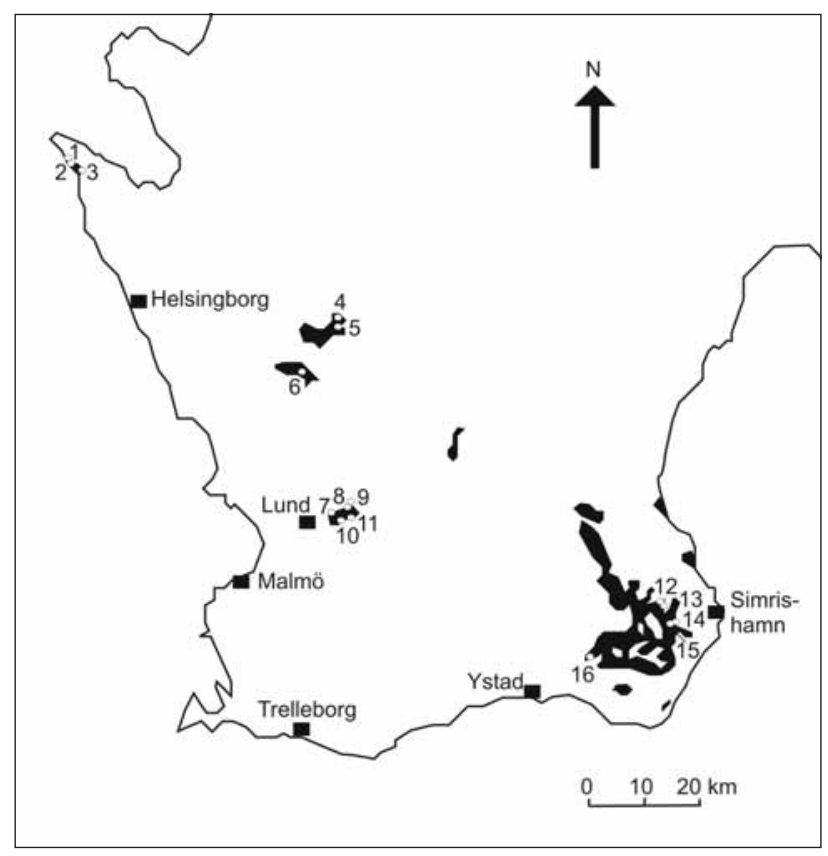

Figure 2. Map showing Ordovician outcrop areas in Skåne. Abbreviations: 1 - Krapperup core, 2 - Nyhamnsläge, 3 - Lovisefred core, 4 - Kyrkbäcken, 5 - Röstånga core, 6 - Rävatofta, 7 - Koängen core, 8 - Cementa 27 core, 9 - Cementa 20 core, 10 - Fågelsång E14b, 11 - Fågelsång core, 12 - Flagabro, 13 - Killeröd, 14 - Ö. Tommarp, 15 - Ö. Tommarp 1-2, 16 - Gärarpsbäcken. Black color shows Ordovician outcrop areas.

depth of $480.80 \mathrm{~m}$ (Ragnar Nilsson, unpublished material, S.M. Bergström 1989). Three samples from the lower Almelund Shale (Didymograptus artus Zone, 426.75-454.00 m) were investigated. A sample at $432.10 \mathrm{~m}$ yielded no chitinozoans. At $437.02 \mathrm{~m}$ Lagenochitina esthonica and Rhabdochitina gracilis occur, and at 439.05-439.10 m Belonechitina micracantha s.1., Conochitina minnesotensis, Cyathochitina calix, Cyathochitina hunderumensis, Lagenochitina esthonica and Rhabdochitina gracilis are present. This is a characteristic early Darriwilian (Llanvirn) chitinozoan assemblage.

Fågelsång core (loc. 11 on Fig. 2). - This well was drilled by Svenska Diamantbergborrnings AB in 1941, and is located by Sularp Brook in the Fågelsång area, about $900 \mathrm{~m}$ SSW of Södra Sandby church. The core penetrates beds from the $N$. gracilis Zone to the Upper Cambrian at a total depth of $55 \mathrm{~m}$. Lithology and macrofossil content were described by Hede (1951), and S.M. Bergström et al. (2002) discussed the well's stratigraphy. Chitinozoans from the Almelund Shale (top within the N. gracilis Zone to the base of the D. murchisoni Zone) are investigated in this study (Fig. 3). The chitinozoan fauna is little diversified, compared to fauna from carbonate facies, but zonal index species are present in the upper Darriwilian to lowermost Sandbian sequence (i.e. Conochitina clavaherculi, Laufeldochitina striata, and L. stentor). Conodonts were discussed by S.M. Bergström et al. (2000). 


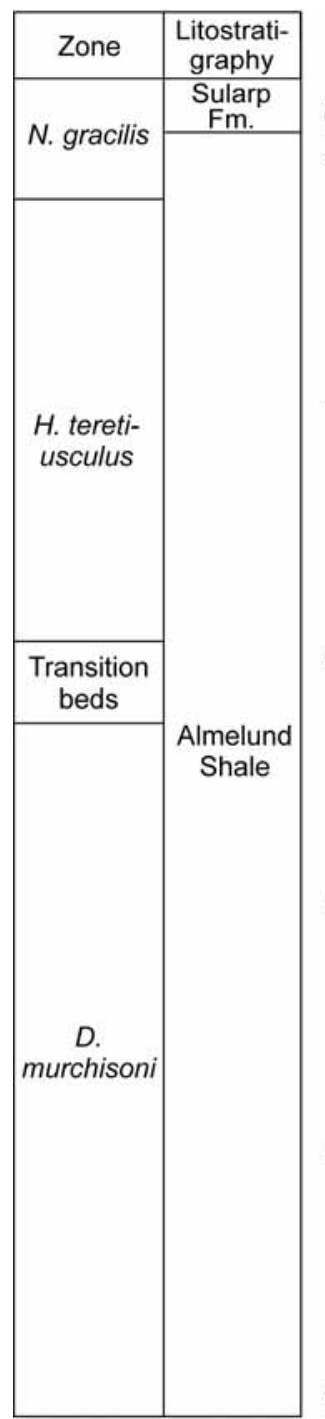

Fågelsång bh.

E14b

(m) continue samples

(m) $\underset{1-1-1-1}{\text { continue samples }}$

10
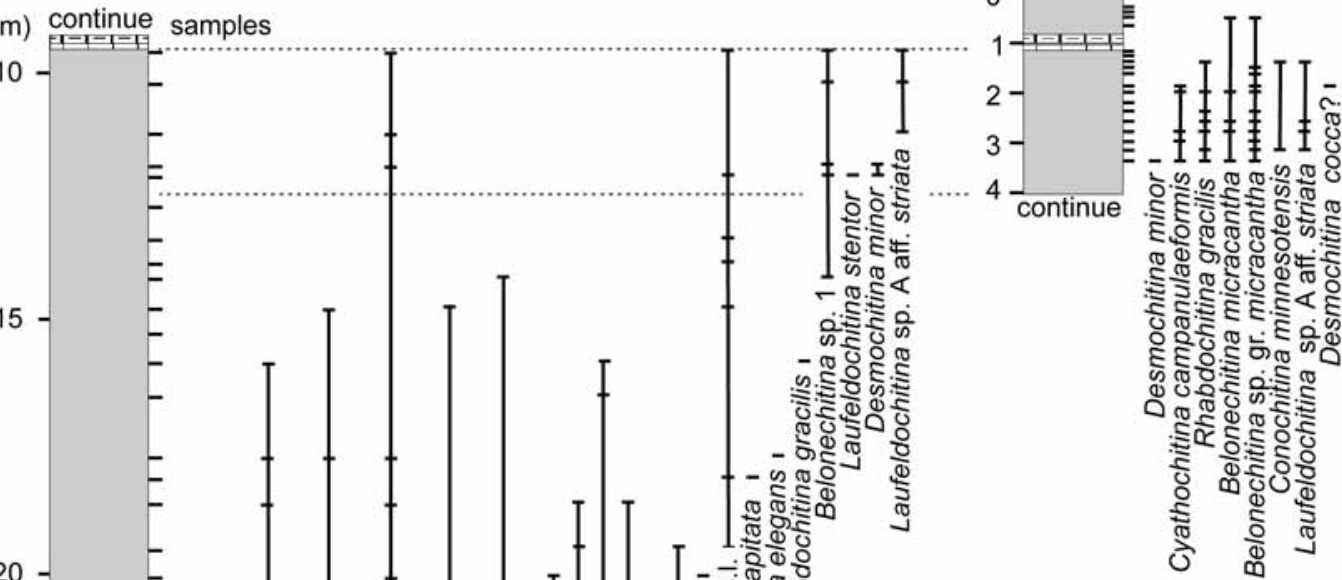

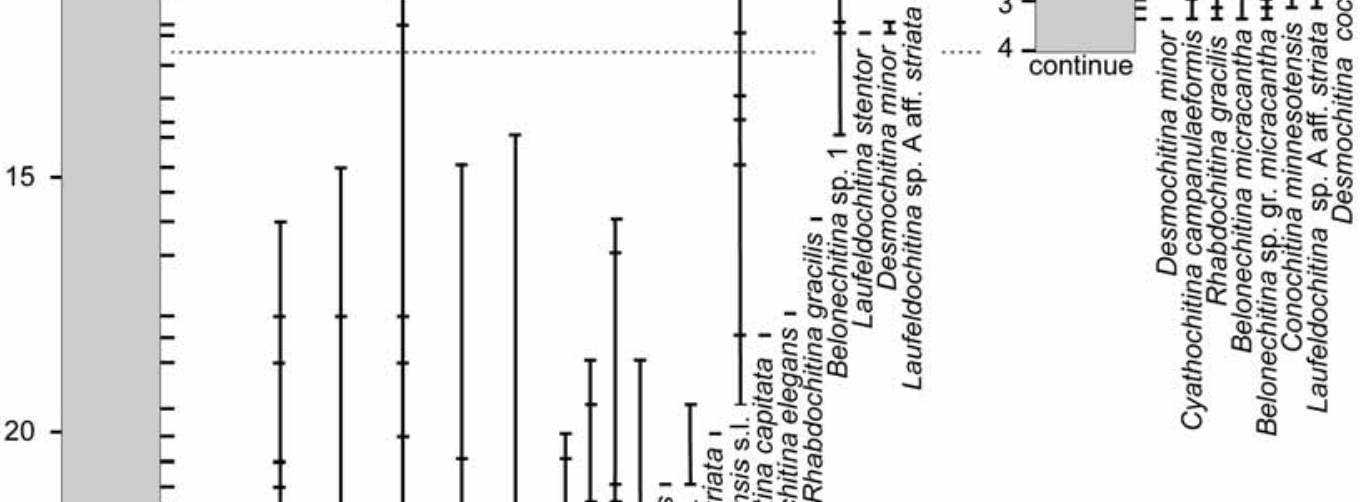

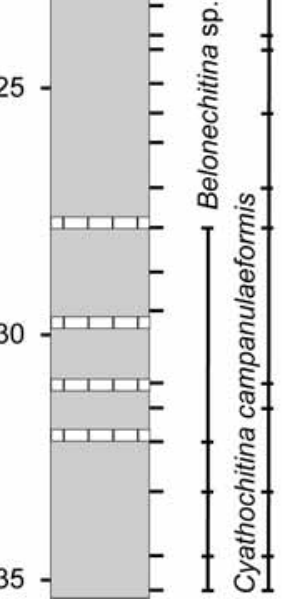

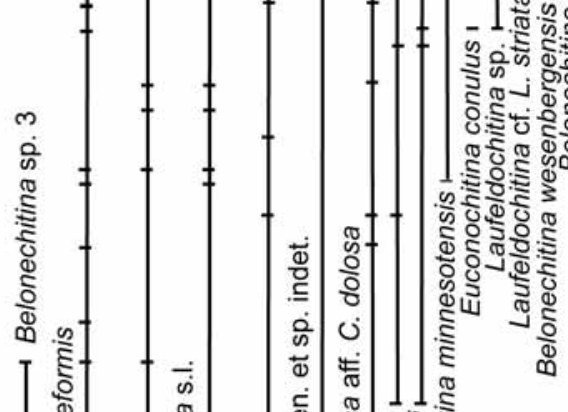

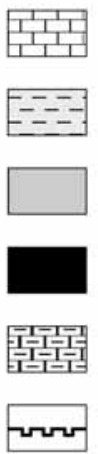

Bedded

limestone

Mudstone

Shale

Bentonite

Phosforite

Major hiatus

Figure 3. Lithology, sample levels and chitinozoan ranges at the E 14b locality and the Fågelsång core. The E 14b locality after Grahn in S.M. Bergström et al. (2000).

Fågelsång E 14 b (loc. 10 on Fig. 2). - This section at Sularp Brook (Fig. 3), about $8 \mathrm{~km} \mathrm{E}$ of the centre of Lund, is the global boundary stratotype for the base of the Upper Series of the Ordovician System (S.M. Bergström et al. 2000). Moberg (1910) was the first to describe the section, and subsequent work has been performed by Hadding (1913), Lindström (1955), S.M. Bergström \& Nilsson (1974), Finney \& S.M. Bergström (1986), S.M. Bergström et al. $(1998,2000)$, as well as others. The chitinozoans were described by Grahn in S.M. Bergström et al. (2000) and Vandenbroucke (2004). The presence of Laufeldochitina sp. A aff. striata, across the Darriwilian-Sandbian boundary, shows that this interval is situated within the upper part of the L. stentor Zone. Lindström (1953) mentioned Conochitina cf. calix (= Cyathochitina campanulaeformis) from the Sularp Formation $40 \mathrm{~m}$ E of Moberg's locality E 38 (about $190 \mathrm{~m} \mathrm{~W}$ of locality E 14 b).
Koängen core (loc. 7 on Fig. 2). - This drilling was carried out by the Svenska Diamantborrningsbolaget in 1954, about $200 \mathrm{~m}$ SE of Koängen Farm, situated about $4.7 \mathrm{~km}$ E of the centre of Lund. Lithology and biostratigraphy were described by Nilsson $(1960,1977)$. The core penetrates a succession, from the lower part of the Lindegård Mudstone downwards to the upper part of the Almelund Shale, for a total depth of $70.30 \mathrm{~m}$. The chitinozoans are investigated in this study (Fig. 4). The chitinozoan biostratigaphy confirms that the Darriwilian-Sandbian boundary to be within the upper part of the L. stentor Zone. The base of Haljala Stage (Armoricochitina granulifera Zone) is distinct, and the occurrence of important key species above (e.g., Spinachitina multiradiata, Desmochitina nodosa, and Belonechitina robusta) makes it easy to correlate the graptolitic facies in the Koängen core with the carbonate facies elsewhere in Sweden. The level of the first occurrence of 


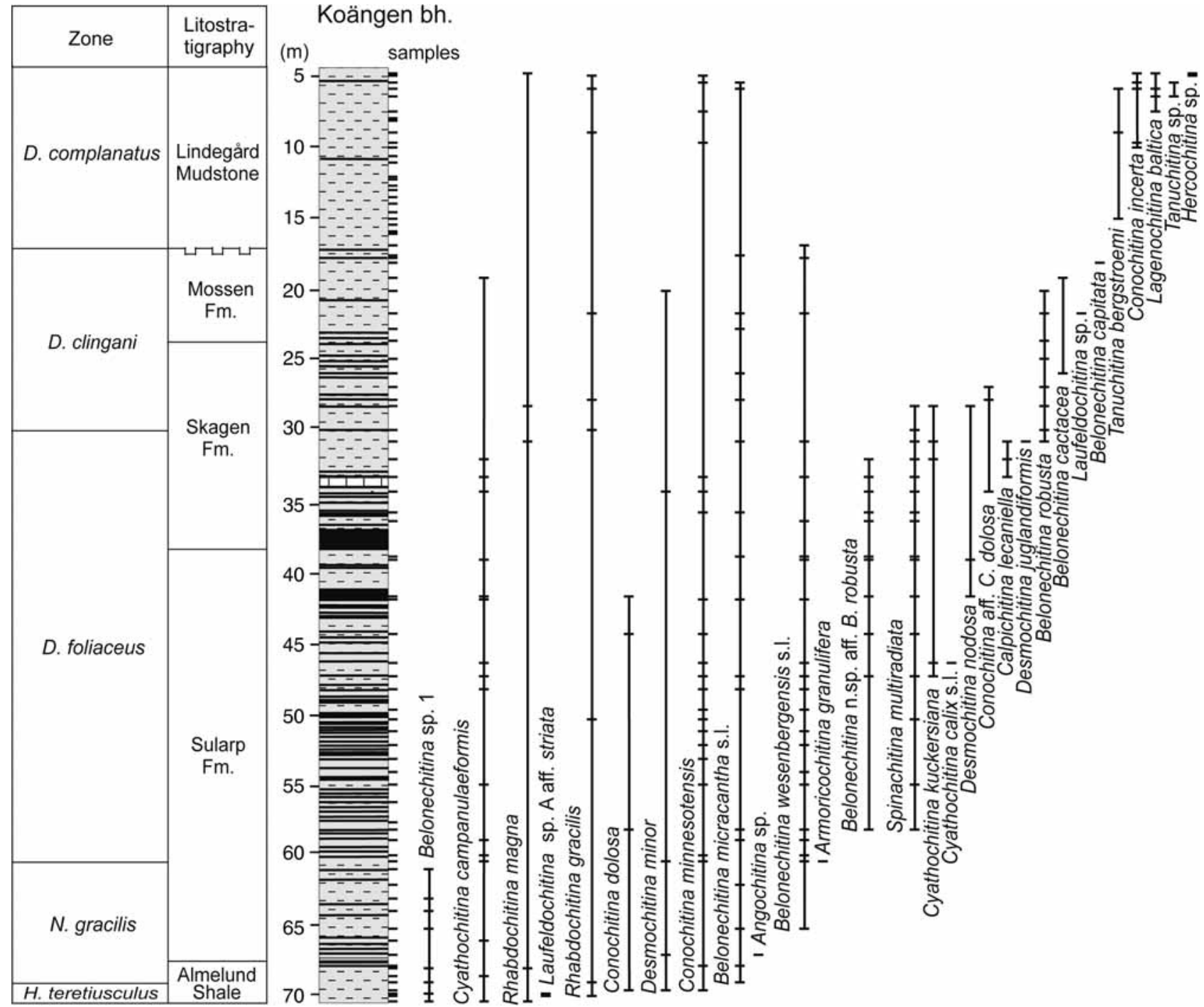

Figure 4. Lithology, sample levels and chitinozoan ranges in the Koängen core.

B. robusta is, roughly, near the base of the Dicranograptus clingani Zone. The presence of the index species Tanuchitina bergstroemi in the Katian sequence restricts the Lindegård Mudstone in the core to the lower part of that unit.

Rävatofta (loc. 6 on Fig. 2). - A temporary ditch-section located at Källeskog Farm $1 \mathrm{~km} \mathrm{~S}$ of Rävatofta, and about $4 \mathrm{~km}$ NE of Svalöv, was excavated in 1967, and exposed Upper Cambrian through Middle Ordovician strata. These rocks and their fossil content were described by J. Bergström et al. (1968). The Skagen Formation yielded Conochitina minnesotensis, Cyathochitina campanulaeformis, Desmochitina minor, and Desmochitina nodosa.

Kyrkbäcken (loc. 4 on Fig. 2). - Along Kyrkbäcken Brook, from about 400-500 m SE of Röstånga church a succession of rocks, representing lower Lindegård Mudstone to the Su- larp Formation, are exposed (Tullberg 1880; Olin 1906; Moberg 1910; Pålsson 1996; S.M. Bergström et al. 1997, 1999). Chitinozoans from the Sularp and Skagen formations were described by Charles Hart in S.M. Bergström et al. (1997), and additional samples from the Mossen Formation were collected by the present authors in 1996 (Fig. 5). The occurrence of Belonechitina robusta in the uppermost part of the Sularp Formation, as well as Euconochitina conulus in both the upper part of the Sularp Formation and in the Skagen Formation, that were reported but not illustrated by S.M. Bergström et al. (1997), are doubtful. Other chitinozoan species present in the section along Kyrkbäcken Brook are confirmed by this study, as well as others (for a summary, see Grahn 1984, Nõlvak \& Grahn 1993).

Gärarpsbäcken (loc. 16 on Fig. 2). - This locality, situated about $850 \mathrm{~m}$ NNW of the Tosterup church, corresponds to 


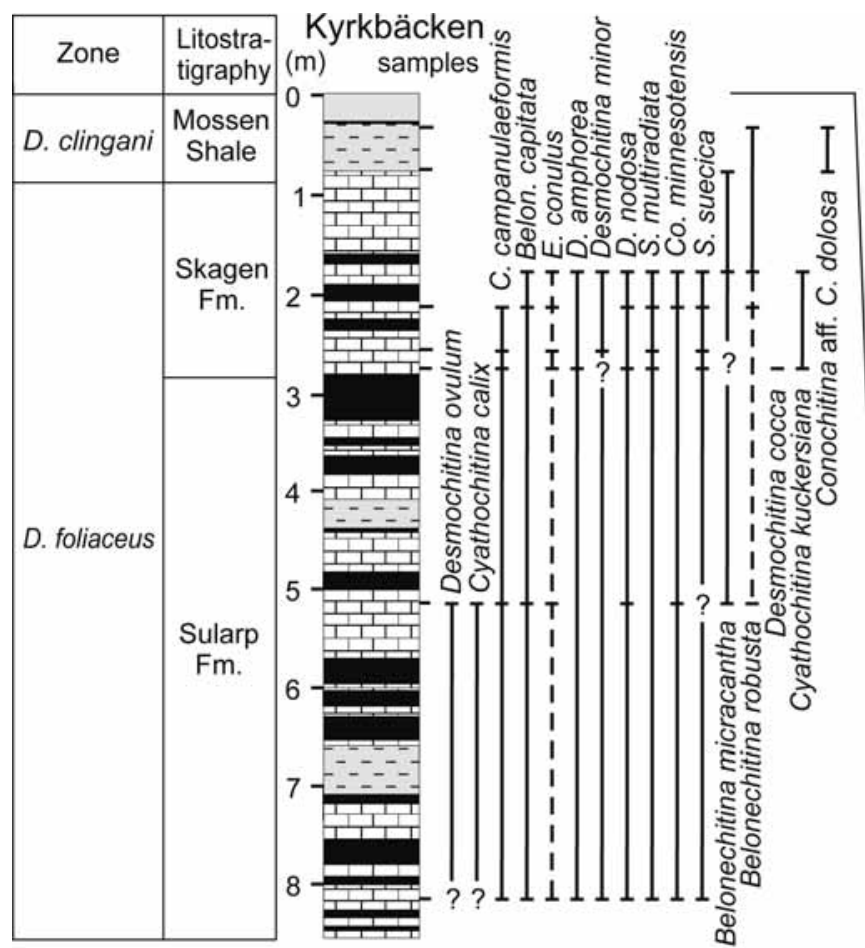

Figure 5. Lithology, sample levels and chitinozoan ranges at the Kyrkbäcken locality and the Röstånga core. Pre-Mossen data in the Kyrkbäcken locality modified after Charles Hart in S.M. Bergström et al. (1997). Abbreviations: C. - Cyathochitina, Belon. - Belonechitina, E. - Euconochitina, D. - Desmochitina, S. - Spinachitina, Co. - Conachitina.

locality BIII: 7 by Moberg (1910, p. 164). It is in the SE valley of the Gärarpsbäcken Brook dark shales, belonging to the Mossen Formation, and crops out in a $\sim 2 \mathrm{~m}$ thick section. Here the graptolites indicate the upper part of the D. clingani Zone. The chitinozoans present, Cyathochitina campanulaeformis and Lagenochitina baltica, agree with this age.

Röstånga core (loc. 5 on Fig. 2). - This drilling was carried out by Borrbolaget (Västra Frölunda), in 1997, about 800 m SE of Röstånga church. The lithology and biostratigraphy was described by S.M. Bergström et al. (1999). The core penetrates lower Silurian to the upper part of the Sularp Formation to a total depth of $132.59 \mathrm{~m}$. Scattered samples through the Lindegård Mudstone and Fjäcka Shale were examined for chitinozoans (Fig. 5). Chitinozoan biostrati-

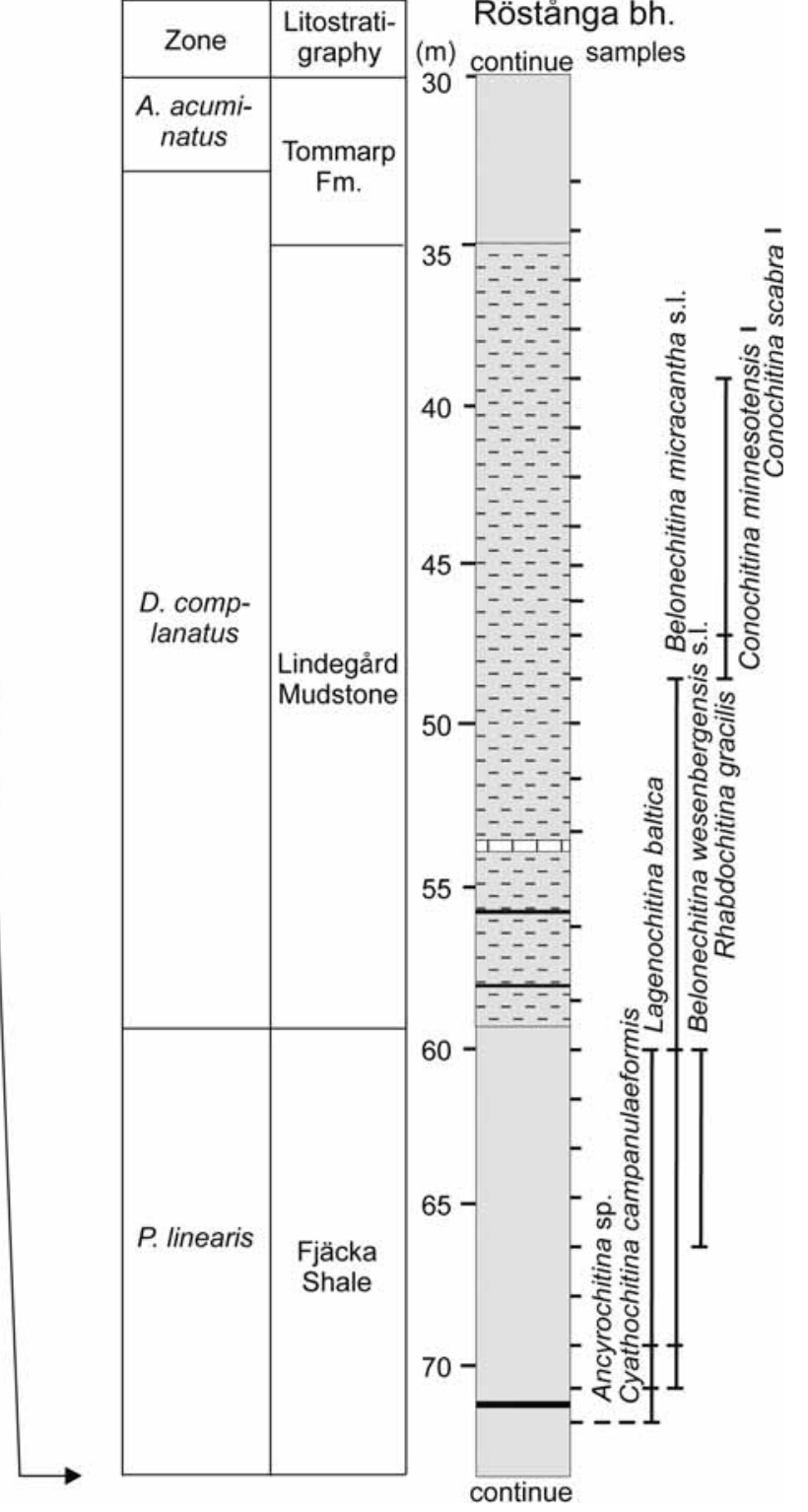

graphy in the Röstånga core is hampered by insufficient sampling; but noteworthy is the presence of Lagenochitina baltica in the Fjäcka Formation, and Conochitina scabra n. sp. in the lower Tommarp Formation, which establish the presence of the $C$. scabra Zone in the core.

Östra Tommarp 1-2 (loc. 15 on Fig. 2). - Ditch-sections, no longer accessible, about 370-380 m WSW of the Östra Tommarp church. In two sections (ÖT 1: from the M. revolutus $=$ cyphus Zone to the base of Silurian, as well as the uppermost $20 \mathrm{~cm}$ of $N$. persculptus Zone and the upper part of the Lindegård Mudstone; and ÖT 2: the upper $74 \mathrm{~cm}$ of $N$. persculptus Zone) comprise a section across the Ordovician-Silurian boundary. Twenty-five samples were collected from the Tommarp Formation and Lindegård Mudstone and investigated for chitinozoans (Grahn 1978) as 


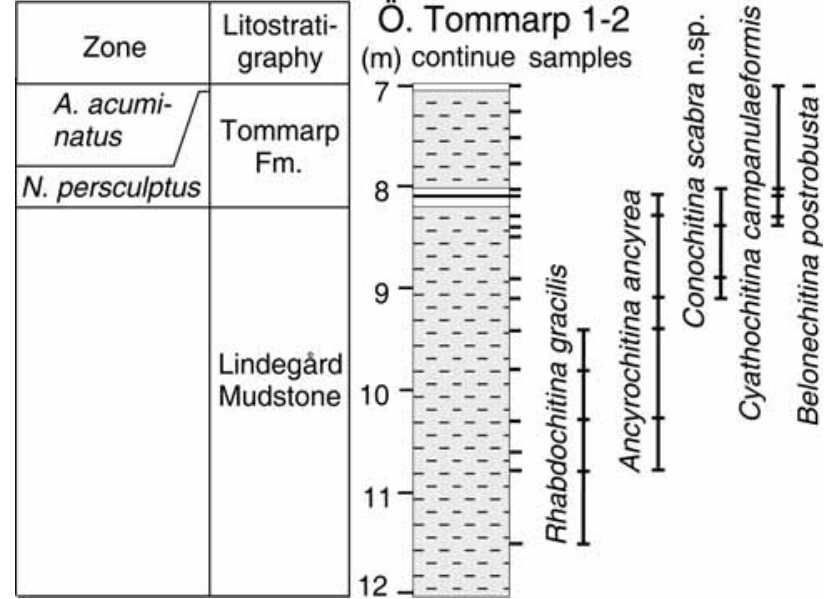

Figure 6. Lithology, sample levels and chitinozoan ranges at the Östra Tommarp 1-2 locality.

well as graptolites (Ragnar Nilsson in Grahn 1998). Chitinozoan biostratigraphy of the lowermost Tommarp Formation (N. persculptus Zone) and Lindegård Mudstone are shown in Fig. 6. The occurrence of the C. scabra Zone at this locality is noteworthy (Grahn 1978).

Cementa 20 core, Fågelsång (loc. 9 on Fig. 2). - This shallow well was carried out by Skånska Cement AB in 1961 about $250 \mathrm{~m} \mathrm{~S}$ of the Södra Sandby church. Twenty-three samples from the Lindegård Mudstone (10.87-23.40 m) were investigated. Only one sample at $17.00 \mathrm{~m}$ yielded Cyathochitina campanulaeformis, a long-ranging, Ordovician to early Silurian, species.

Cementa 27 core, Fågelsång (loc. 8 on Fig. 2). - This shallow well was carried out by Skånska Cement AB in 1961 about $160 \mathrm{~m} \mathrm{NW}$ of the Lindegård Farm, and about $850 \mathrm{~m}$ WNW of the Södra Sandby church. The macrofossils were described by Nilsson (1979) and the chitinozoans by Grahn (1978 as Södra Sandby 27). From the Ordovician sequence, four samples from the lower part of the Tommarp Formation (N. persculptus Zone) and upper part of the Lindegård Mudstone (from 17.40 m downwards) were investigated. Three species are present, i.e. Ancyrochitina ancyrea at 17.60-17.70 m, Conochitina scabra (Conochitina robusta by Grahn, 1978) at 17.00-17.05 and 17.15-17.30 m, and Cyathochitina campanulaeformis at 17.00-17.05 and 18.00-18.05 m. S.M. Bergström et al. (1999) used the Hirnantian and Silurian stratigraphy of the well in a regional correlation.

Nyhamnsläge (loc. 2 on Fig. 2). - Surface exposure across the Ordovician-Silurian boundary at the beach about $3150 \mathrm{~m}$ WSW of the Brunnby church (Grahn 1978). The locality has also been described by Lundgren (1874), Lindström (1880), Törnquist (1875), Troedsson (1918, 1920), and
Grahn (1978). Rhabdochitina gracilis, a long-ranging Ordovician species, is present in the upper part of the Lindegård Mudstone (Sven Laufeld, pers. comm. 1978).

The following samples were barren of chitinozoans: The Björkåsholmen Formation at Flagabro Farm (loc. 12 on Fig. 2), 1960 m NNE of the Smedstorp church (Regnéll 1955, 1960; Eisenack 1968, p. 186; Tjernvik 1958), and the Alum Shale Formation along Flagabro Brook (unpublished information).

The Killeröd Formation (Nilsson 1952; Regnéll 1960; J. Bergström 1982; and Månsson 1995) at Killeröd (loc. 13 on Fig. 2), situated about $500 \mathrm{~m}$ SE of Flagabro Farm, and the Komstad Limestone in the adjacent Killeröd quarry.

A ditch section at Östra Tommarp (loc. 14 on Fig. 2), no longer accessible, about $600 \mathrm{~m}$ WSW of the Östra Tommarp church, described by Olin (1906) and Funkquist (1919), and commented upon by both S.M. Bergström \& Nilsson (1974) and S.M. Bergström et al. (1997). That section yielded a condensed sequence from the Komstad Limestone to the Mossen Formation (S.M. Bergström et al. 1997).

\section{Bornholm}

The Danish island of Bornholm is situated ca $33 \mathrm{~km}$ southeast of the mainland of Sweden (Fig. 1). The island is located along the southwestern margin of the Baltic Shield, and it was a stable Precambrian platform until Ludlow time (Troedsson 1932, Bjerreskov \& Stouge 1985). Small outliers of Ordovician rocks occur in fault blocks, tilted in low angles, in the southwestern part of the island, along the main streams Læså and Øleå (Fig. 7). Relief was re-activated by the Caledonian orogeny and caused huge amounts of sediment accumulation in the Polish trough (Bjerreskov \& Stouge 1985). Hiatuses in the Ordovician sequence of Bornholm are of a magnitude difficult to explain by periods of marine non-sedimentation; and according to Poulsen \& Poulsen (1979) the area was continental during periods of the Ordovician. However, this is not supported by sedimentological data (Krarup Pedersen 1989). The total thickness is estimated to be about $40 \mathrm{~m}$. Three localities have been investigated, and are described below in stratigraphic order.

Vasegård (Fig. 7). - This classical locality along Læså Brook, and about $2.7 \mathrm{~km} \mathrm{SW}$ of the Åkirkeby church, displays strata from the lowermost part of the Skagen Formation to the lower part of the Lindegård Mudstone. Lithology and stratigraphy have been described by, among others, Hadding (1915a, b), Funkquist (1919), and Gry (1948). Beds 2-3 in Funkquist's well section at Vasegård (Funkquist 1919, p. 31) have yielded Spinachitina (Belonechitina) suecica and Desmochitina "rugosa" according to Sven Laufeld in S.M. Bergström \& Nilsson (1974, p. 31). 


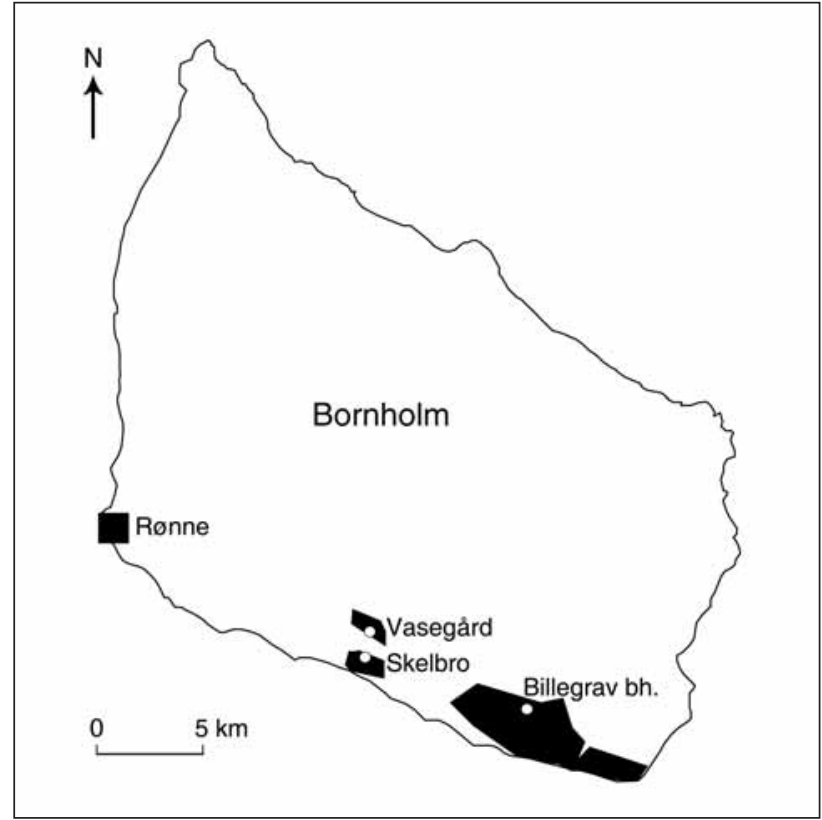

Figure 7. Map showing Ordovician outcrop areas and the localities on Bornholm. Black color shows Ordovician outcrop areas.

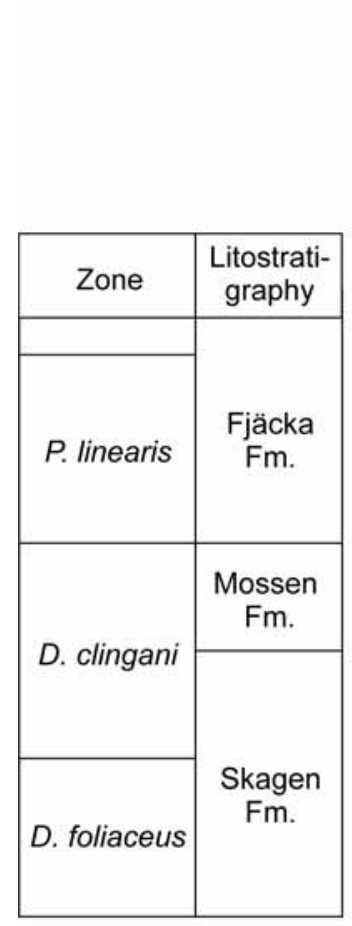

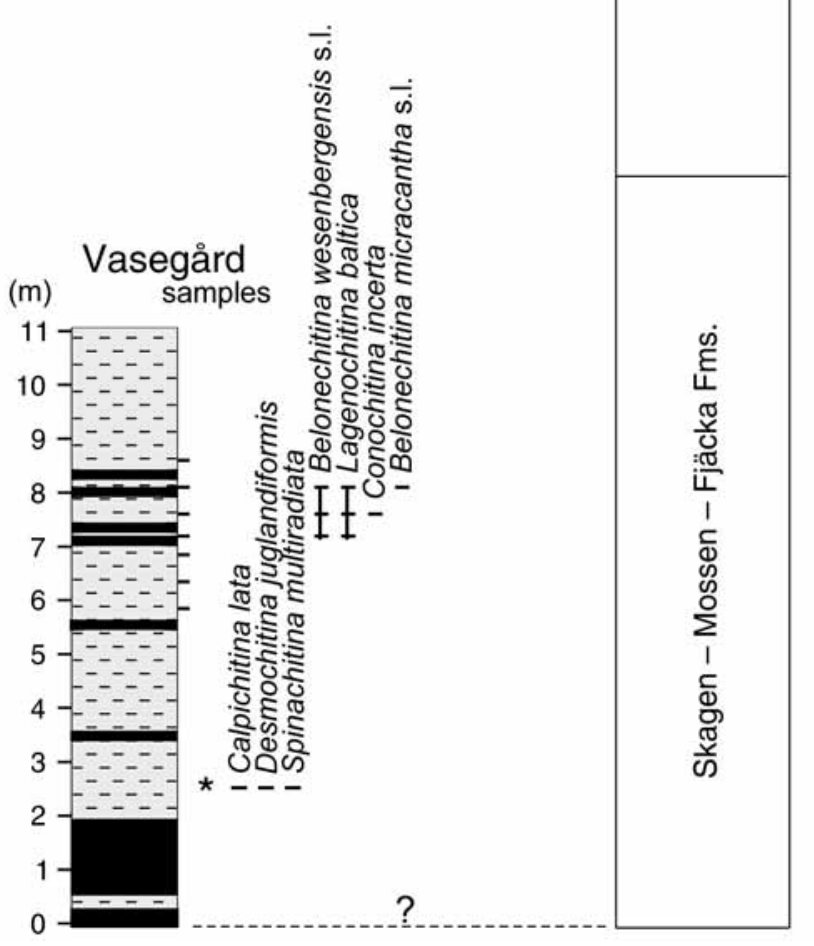

\section{Billegrav bh.}
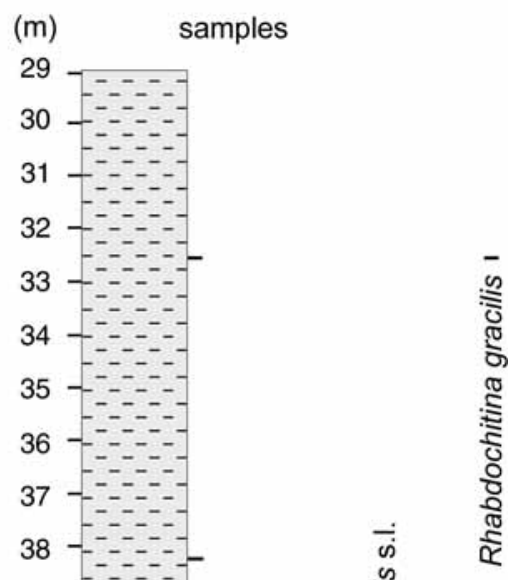

Lindegård

Mudstone

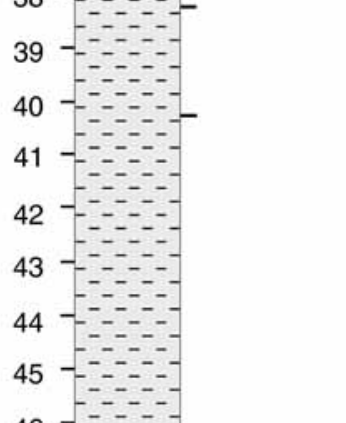

46

47

48

49

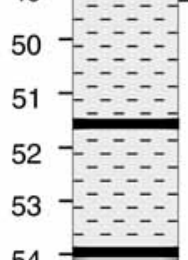

54

55

56

57

58

59

60

61

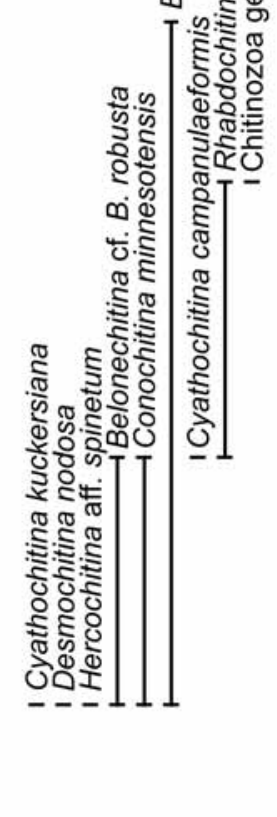

Figure 8. Lithology, sample levels and chitinozoan ranges at the Vasegård locality and the Billegrav core. * - chitinozoan occurrences after Laufeld in S.M. Bergström \& Nilsson (1974, p. 31).

Specific levels were sampled for chitinozoans by S.M. Bergström \& Nilsson (1974, p. 31) and by the senior author in 1990 (Fig. 8). The chitinozoans shows a striking similarity to those in Skåne.

Billegrav core (Fig. 7). - This shallow well, performed by the Geological Survey of Greenland in 1984, and situated about $1875 \mathrm{~m}$ ESE of Pederskirke, penetrates the lowermost Silurian down to the lowermost part of the Skagen Formation (Krarup Pedersen 1989). Ordovician rocks from the uppermost part of the Lindegård Mudstone to the base of the well have been investigated in this study (Fig. 8). 
The few chitinozoans encountered are the same as contemporaneous species in Skåne.

Samples from the Komstad Limestone at Skelbro Quarry (Fig. 7), about $4150 \mathrm{~m} \mathrm{SW}$ of the Åkirkeby church, yielded no chitinozoans. However, Laufeld (1967, p. 281) reported the presence of chitinozoans in this limestone from Bornholm, although, without any taxonomic information.

\section{Systematic palaeontology}

Systematic inventory of chitinozoan species in alphabetical order by genus and species:

Ancyrochitina ancyrea (Eisenack, 1931)

Ancyrochitina sp. - Fig. 11A, B

Angochitina sp. - Fig. 11C

Armoricochitina granulifera Nõlvak \& Grahn, 1993

Belonechitina cactacea (Eisenack, 1937)

Belonechitina capitata (Eisenack, 1962)

Belonechitina micracantha s.1. (Eisenack, 1959) - Fig. 11D

Belonechitina robusta (Eisenack, 1959)

Belonechitina cf. B. robusta (Eisenack, 1959) - Fig. 11E

Belonechitina n. sp. aff. B robusta (Eisenack, 1959) -

Fig. 11F

Belonechitina wesenbergensis s.1. (Eisenack, 1959) -

Fig. $11 \mathrm{G}$

Belonechitina sp. 1 sensu Vandenbroucke, 2004

Belonechitina sp. 3 sensu Vandenbroucke, 2004

Calpichitina lata (Schallreuter, 1963)

Calpichitina lecaniella (Eisenack, 1965)

Conochitina clavaherculi Eisenack, 1959

Conochitina dolosa Laufeld, 1967

Conochitina aff. C. dolosa Laufeld, 1967 - Fig. 11H

Conochitina elegans Eisenack, 1931

Conochitina incerta Eisenack, 1962

Conochitina minnesotensis Stauffer, 1933

Conochitina scabra n. sp. - Fig. 11I

Cyathochitina calix (Eisenack, 1931)

Cyathochitina campanulaeformis (Eisenack, 1931)

Cyathochitina hunderumensis Grahn, Nõlvak \& Paris, 1996

Cyathochitina kuckersiana (Eisenack, 1934)

Desmochitina amphorea Eisenack, 1931

Desmochitina cocca Eisenack, 1931

Desmochitina juglandiformis Laufeld, 1967

Desmochitina minor Eisenack, 1931

Desmochitina nodosa Eisenack, 1931

Desmochitina ovulum Eisenack, 1962

Desmochitina “rugosa” Eisenack, 1962

Euconochitina conulus (Eisenack, 1955)

Hercochitina aff. spinetum Melchin \& Legault, 1985

Hercochitina sp. - Fig. 11J

Lagenochitina baltica Eisenack, 1931
Lagenochitina esthonica Eisenack, 1955

Laufeldochitina stentor (Eisenack, 1937)

Laufeldochitina striata (Eisenack, 1937)

Laufeldochitina cf. L. striata (Eisenack, 1937) - Fig. 11K

Laufeldochitina sp. A aff. striata Grahn, Nõlvak \& Paris, 1996

Laufeldochitina sp. - Fig. 11L

Rhabdochitina gracilis Eisenack, 1962

Rhabdochitina magna Eisenack, 1931

Spinachitina multiradiata (Eisenack, 1959)

Spinachitina suecica (Laufeld, 1967)

Tanuchitina bergstroemi Laufeld, 1967

Tanuchitina sp. - Fig. 11M

The regional stratigraphic ranges for the Ordovician chitinozoans from Skåne and Bornholm are given in Fig. 9. The taxonomy follows the scheme by Paris et al. (1999). Chitinozoan species in open nomenclature, not earlier discussed in the literature and problematic species will be described below.

Group Chitinozoa Eisenack, 1931

Order Operculatifera Eisenack, 1972

Family Desmochitinidae Eisenack, 1931

Subfamily Desmochitininae Paris, 1981

Genus Desmochitina Eisenack, 1931

Type species. - Desmochitina nodosa Eisenack, 1931.

\section{Desmochitina "rugosa" Eisenack, 1962}

Remarks. - The rugose nature of the vesicle wall of this species is not an original feature, mainly D. minor and $D$. amphorea and sometimes D. ovulum are probably covered with a secondary layer, which makes the identifications uncertain, without specific preparations. Desmochitina "rugosa" is therefore considered as a complex of different Desmochitina species.

Occurrence. - Vasegård section, lower part of the Skagen Formation, Bornholm.

Order Prosomatifera Eisenack, 1972

Family Conochitinidae Eisenack, 1931 emend. Paris, 1981

Subfamily Conochitininae Paris, 1981

Genus Conochitina Eisenack, 1931 emend. Paris, Grahn, Nestor \& Lakova, 1999

Type species. - Conochitina claviformis Eisenack, 1931. 
Yngve Grahn \& Jaak Nõlvak • Ordovician Chitinozoa from Skåne and Bornholm

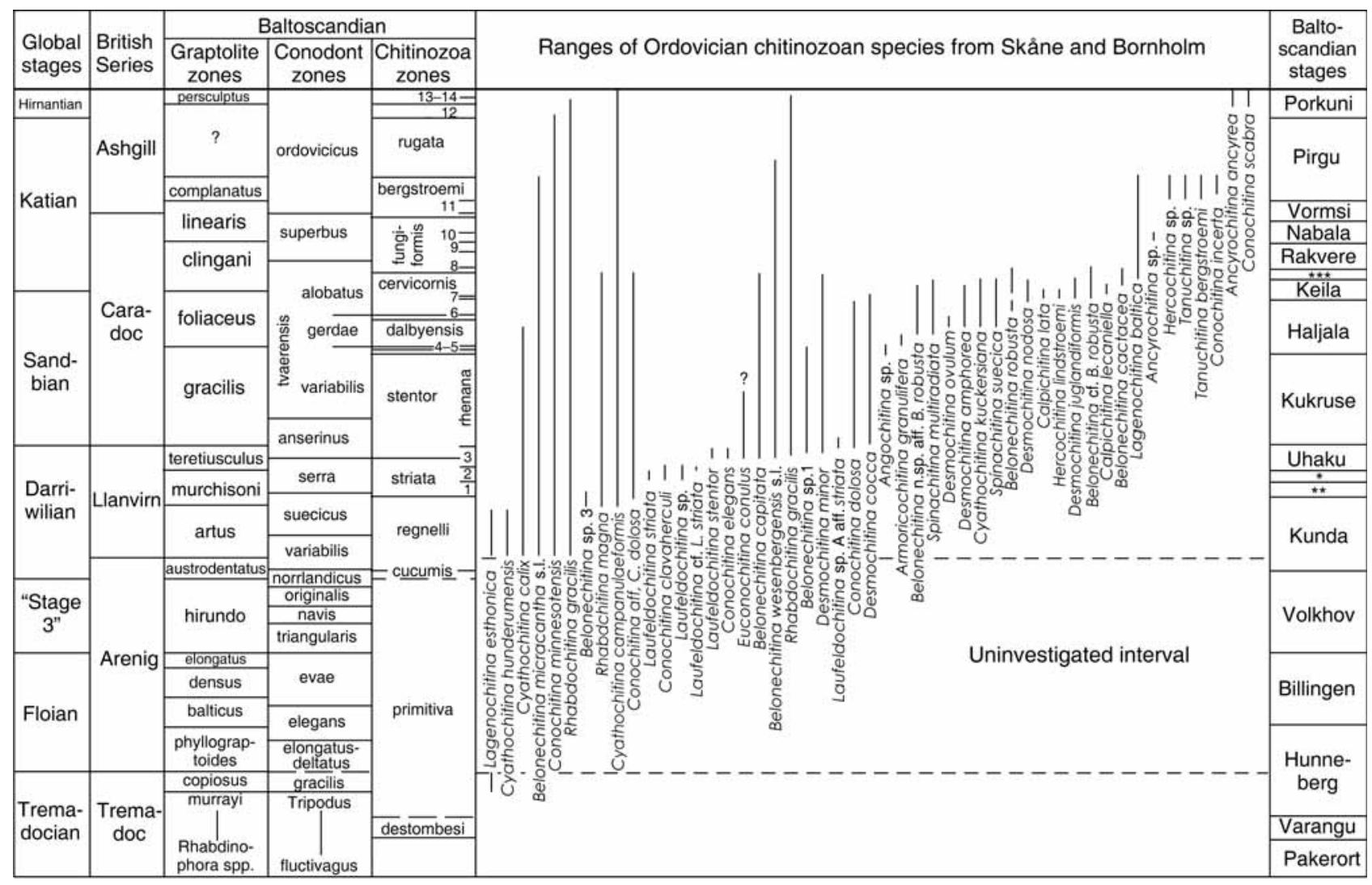

Figure 9. Correlation table of Ordovician strata and the stratigraphic ranges of chitinozoan species in Skåne and Bornholm. Abbreviations: 1 - Cyathochitina sebyensis subzone, 2 - Conochitina clavaherculi subzone, 3 - Conochitina tuberculata subzone, 4 - Armoricochitina granulifera Zone, 5 - Angochitina curvata Zone, 6 - Belonechitina hirsuta Zone, 7 - Angochitina multiplex subzone, 8 - Ancyrochitina sp. 1 subzone, 9 - Cyathochitina angusta subzone, 10 - Armoricochitina reticulifera subzone, 11 - Acanthochitina barbata subzone, 12 - Belonechitina gamachiana Zone, 13 - Spinachitina taugourdeaui Zone, 14 - Conochitina scabra Zone, * - Lasnamägi Stage, ** - Aseri Stage, *** - Oandu Stage.

Conochitina aff. C. dolosa Laufeld, 1967 Figure $11 \mathrm{H}$

Description. - An elongated conical almost claviform species with smooth vesicle wall.

Remarks. - Conochitina aff. C. dolosa differs from C. dolosa Laufeld, 1967 in having a weakly developed mucro and an indistinct flexure.

Occurrence. - Lower part of the Almelund Shale to lower part of the Mossen Formation, Skåne.

\section{Conochitina scabra n. sp.}

Figure 11I

1978 Conochitina robusta Grahn; Fig. 4A, B, D, G.

1993 Conochitina scabra nom. nud.; Nõlvak \& Grahn, pl. IVE.

Derivation of name. - Latin, scaber, rough or rugged, referring to the surface ornamentation.
Holotype. - Ch 914/7609, Kardla core, level 167.5 m, Kuldiga Formation, Porkuni Stage, South Estonia, Nõlvak \& Grahn 1993, Pl. IVE.

Type interval and locality. - Kardla core, interval 167.5-181.3 m.

Holotype dimensions ( $\mu \mathrm{m}$ ). - Total length 217, maximum width 77 , width of aperture 56.

Dimensions $(\mu m)$. - 45 specimens from different samples from the Kardla core interval 167.5-181.3 m. Total length 140-266, mean 223; maximum width 63-98, mean 78; width of aperture 56-63, mean 58.

Diagnosis. - A species of Conochitina with a subcylindrical glabrous chamber provided with a mucron; flexure and shoulder lacking or inconspicuous; vesicle wall sometimes randomly ornamented with less than $2 \mu \mathrm{m}$ high microgranules.

Description. - This species displays the main characteristics of the genus Conochitina Eisenack, 1931, emend. Pa- 


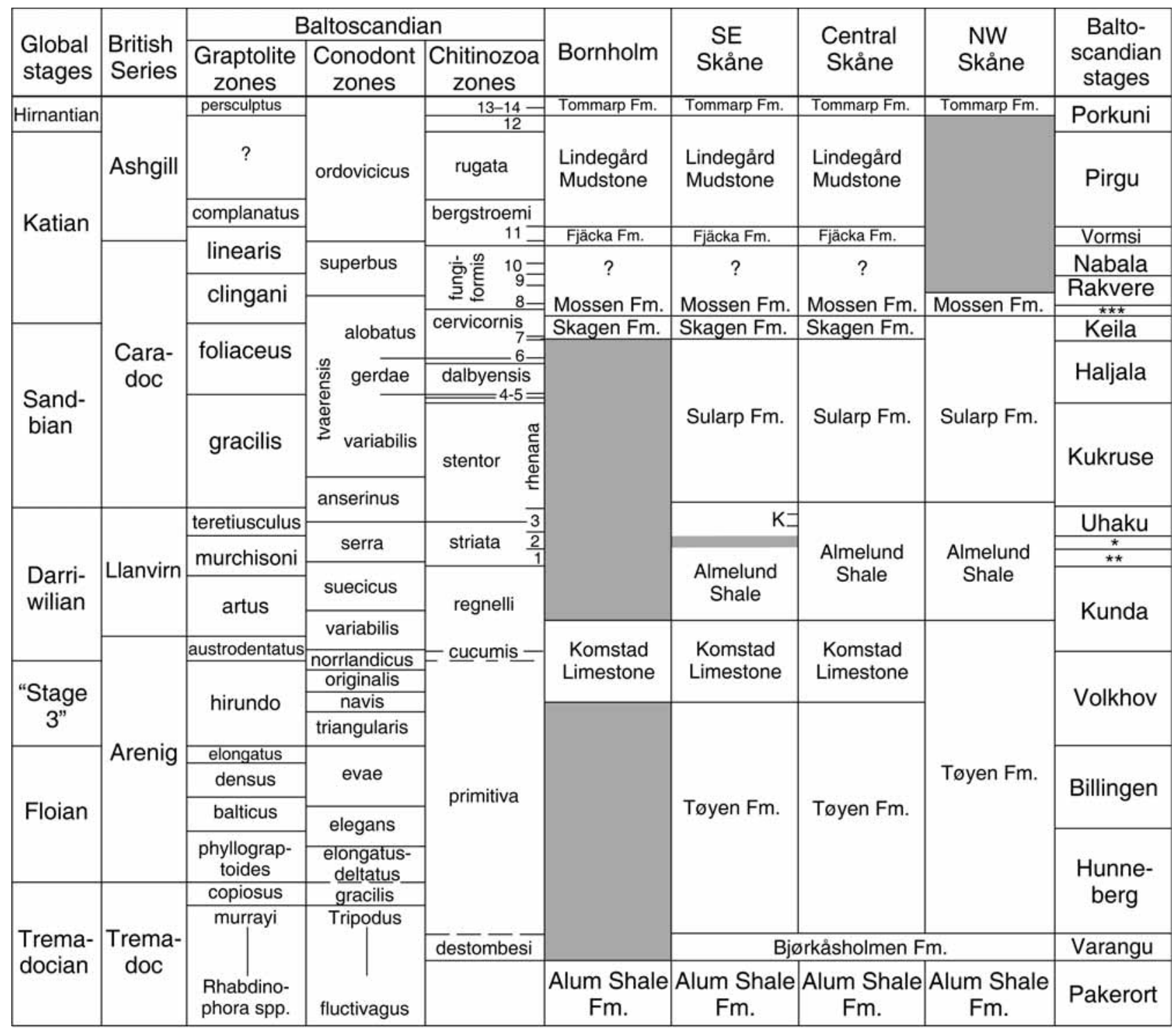

Figure 10. Chrono- and lithostratigraphy in the Ordovician of Skåne and Bornholm. Abbreviations: K - Killeröd Formation. For other abbreviations, see Fig. 9.

ris, Grahn, Nestor \& Lakova, 1999. The vesicle is subcylindrical with straight to slightly convex flanks. Shoulders and flexure are absent or weakly developed, and the neck, if present, is about $1 / 3$ of the total length of the vesicle. The maximum width of the vesicle is just above the basal margin. The basal part or body sometimes bears conical tubercles or microgranules, which are better developed near the rounded basal margin, decreasing gradually towards the aperture. Microgranules sometimes also occur on the marginal part of the convex base. Their density varies in different specimens. Microgranules are more characteristic in populations from both the lowermost and uppermost parts of the species' stratigraphical range. If well preserved, rare specimens may have a spiny aperture.

Discussion. - C. scabra n. sp. is a polymorph species and differs from the Silurian zonal index species Belonechitina postrobusta (Nestor, 1980) mainly in having no spines, whereas dimensions often are similar. The same is true comparing with the very variable $B$. micracantha (Eisenack, 1931), where typical specimens are spiny and more conical, and they have a more distinct flexure and a more pronounced basal edge. However, transitional forms occur. B. gamachiana (Achab, 1989) and B. parvispinata Soufiane \& Achab, 2000 have a more pronounced ornamentation, and the latter also has a club-shaped body. C. scabra n. sp. is the index species for the C. scabra total range Zone (Nõlvak \& Grahn 1993).

Occurrence. - In the topmost part of the Porkuni Stage, as the uppermost Ordovician zonal index species (Nõlvak \& Grahn 1993), found in core sections of southern Estonia: 
Valga (Nõlvak 2001), Ruhnu (Nõlvak 2003), Kardla, Taagepera (Brenchley et al. 2003), Ohesaare, Tartu, Elva, and Laeva; in Latvia at: Riekstini (Brenchley et al. 2003), Baldone, Baltinava, and Vilcini; in western Lithuania at: Butkunai, and Taučionys; in northwestern Russia at: Iljinskoje (Brenchley et al. 1997); an in southern Sweden at: Ö. Tommarp 1-2 section, uppermost part of the Lindegård Mudstone to lowermost part of the Tommarp Formation (lower $N$. persculptus Zone), as well as the Röstånga core (level $34.5 \mathrm{~m}$ ), lowermost part of the Tommarp Formation, Skåne.

Material. - About one thousand specimens from different sections.

Subfamily Tanuchitininae Paris, 1981

\section{Genus Laufeldochitina Paris, 1981}

Type species. - Cyathochitina stentor (Eisenack, 1937).

\section{Laufeldochitina cf. L. striata (Eisenack, 1937) Figure 11K}

Description. - Laufeldochitina cf. L. striata differs from L. striata in its smaller size and in not having a striate ornamentation on the vesicle wall.

Occurrence. - Fågelsång core (level 20.06-20.16 m), middle part of the Almelund Shale, Skåne.

\section{Laufeldochitina sp.}

Figure 11L

Description. - A Laufeldochitina species with an ovoid body with truncated base and a short carina below the basal margin. The neck is long, cylindrical and with a straight aperture. Vesicle wall smooth.

Remarks. - This species precedes Laufeldochitina stentor in the stratigraphic column in Skåne, and differs from that species in the lack of vesicle wall ornamentation.

Occurrence. - Fågelsång core (levels 19.4-19.5 m and 21-21.2 m), middle part of the Almelund Shale, Skåne.

Genus Tanuchitina Jansonius, 1964 emend. Paris, Grahn, Nestor \& Lakova, 1999

Type species. - Tanuchitina ontariensis Jansonius, 1964.

\section{Tanuchitina sp.}

Figure 11M

Description. - A Tanuchitina species with an ovoid and elongated vesicle. The base is truncated, and a short carina occurs at the margin. The flexure is indistinct. Vesicle wall smooth.

Remarks. - The bad preservation and the scarce occurrence of this species prevent its description as a new species.

Occurrence. - Koängen core (levels 5.55-5.65 m and 6.40-6.45 m), lower part of the Lindegård Mudstone, Skåne.

Subfamily Belonechitininae Paris, 1981

\section{Genus Belonechitina Jansonius, 1964}

Type species. - Conochitina micracantha subsp. robusta Eisenack, 1959.

\section{Belonechitina micracantha s.l. (Eisenack, 1931) Figure 11D}

Remarks. - Some of the specimens designated as Belonechitina sp. gr. micracantha by Grahn (in S.M. Bergström et al. 2000) were later subdivided into Belonechitina sp. 1-3 by Vandenbroucke (2004). This subdivision has been maintained in all investigated sections except for the section at Fågelsång E 14b (Fig. 3). Eisenack (1959) defined Belonechitina micracantha (his Conochitina micracantha micracantha) as a species with an elongated conical body provided with a constriction aperturewards of the basal edge (Eisenack 1959, pl. 1, fig. 5 therein), and a vesicle covered by simple spines. Specimens that fit the general description of $B$. micracantha micracantha, but do not clearly display the constriction near the basal edge are here included in Belonechitina micracantha s.1., which also includes specimens with a more rounded base than the type material.

Occurrence. - Lower part of the Almelund Shale to lower part of the Lindegård Mudstone, Skåne.

\section{Belonechitina cf. B. robusta (Eisenack, 1959)} Figure 11E

Description. - The nature of the complete ornamentation of this species has not been observed. The general outline is that of Belonechitina robusta, and it is therefore referred to as Belonechitina cf. B. robusta. 
Occurrence. - Billegrav core (levels 54.35 and $59 \mathrm{~m}$ ), lowermost part of the Skagen Formation to Mossen Formation, Bornholm.

\section{Belonechitina n. sp. aff. B. robusta (Eisenack, 1959) Figure $11 \mathrm{~F}$}

Description. - This species differs from Belonechitina robusta in having predominantly simple spines. The present material is not numerous or well-preserved to allow a formal designation to a new species.

Remarks. - Schallreuter $(1981,1983)$ included this species from Gotland and Västergötland (Sweden) in his Belonechitina repsinata, a species that has multirooted spines, and thus is a junior synonym to Belonechitina robusta (Eisenack, 1959). Furthermore, Schallreuter's type material came from erratics, presumably from the Sularp Formation in Skåne. Our observations show that rare occurrences of B. robusta are known from the same stratigraphic interval in carbonate facies from Dalarna, north central Sweden.

Occurrence. - Upper part of the Sularp Formation to middle part of the Skagen Formation, Skåne.

\section{Belonechitina wesenbergensis s.l. (Eisenack, 1959) Figure 11G}

Remarks. - Eisenack (1959) defined Belonechitina wesenbergensis (his Conochitina wesenbergense) as a species with an elongated conical, almost cylindrical, body and a cylindrical neck, and a vesicle covered by simple spines. Later (Eisenack 1972) divided this species into a short form defined as $C$. wesenbergensis brevis and a longer form defined as $C$. wesenbergensis elongata. The difference between these two subspecies is the size. In the Scandinavian material these two subspecies have not been separated. In Estonia they have the same stratigraphic range, although they might be mutually exclusive. Specimens that fit the general description of $B$. wesenbergensis, but do not clearly display a distinct flexure and the cylindrical neck, as well as the two subspecies defined by
Eisenack (1965), are here included in Belonechitina wesenbergensis s.1.

Occurrence. - Upper part of the Almelund Shale to lower part of the Lindegård Mudstone, Skåne and from the Skagen Formation to the lower part of the Lindegård Mudstone, Bornholm.

\section{Genus Hercochitina Jansonius, 1964}

Type species. - Hercochitina crickmayi Jansonius, 1964.

\section{Hercochitina sp.}

Figure 11J

Description. - A Hercochitina species with a conical body, rounded base, and a short cylindrical neck. About 16-18 ridges of connected simple spines cover the vesicle. The vesicle wall between these ridges is smooth. The flanks are convex and the aperture straight.

Remarks. - Similar specimens (Hercochitina sp. B) occur at the same stratigraphic position in the Oslo Region (Grahn et al. 1994), but they differ from the present material in their more cylindrical body.

Occurrence. - Koängen core (levels 4.85 and 4.92-4.96 m), lower part of the Lindegård Mudstone, Skåne.

Family Lagenochitinidae Eisenack, 1931

Subfamily Angochitininae Paris, 1981

\section{Genus Angochitina Eisenack, 1931}

Type species. - Angochitina echinata Eisenack, 1931.

\section{Angochitina sp.}

Figure 11C

Description. - An Angochitina species with an ovoid body and cylindrical neck. The vesicle wall is provided with ran-

Figure 11. Selected Ordovician Chitinozoa from Skåne and Bornholm. The scale bar represents $100 \mu \mathrm{m}$. $・ \mathrm{~A}-$ Ancyrochitina sp. Röstånga core, level 72 m. Fjäcka Formation. • B - Ancyrochitina sp. Röstånga core, level 72 m. Fjäcka Formation. • C - Angochitina sp. Koängen core, level 67 m. Sularp Formation. • D - Belonechitina micracantha s.l. (Eisenack, 1931). Vasegård section, ca $1 \mathrm{~m}$ above top of the Mossen Formation. Fjäcka Formation. $\bullet$ E - Belonechitina cf. B. robusta (Eisenack, 1959). Billegrav core, level 59 m. Skagen Formation. • F - Belonechitina n. sp. aff. B. robusta (Eisenack, 1959). Koängen core, level 34.02-34.12 m. Skagen Formation. • G - Belonechitina wesenbergensis s.1. (Eisenack, 1959). Billegrav core, level 59 m. Skagen Formation. • H - Conochitina aff. C. dolosa Laufeld, 1967. Fågelsång core, level 31.50-31.60 m. Almelund Shale. $\bullet$ I - Conochitina scabra n. sp. Röstånga core, level 34.5 m. Tommarp Formation. • J - Hercochitina sp. Koängen core, level 4.92-4.96 m. Lindegård Mudstone. $\bullet$ K - Laufeldochitina cf. L. striata (Eisenack, 1937). Fågelsång core, level 20.06-20.16 m. Almelund Shale. • L - Laufeldochitina sp. Fågelsång core, level 21.00-21.20 m. Almelund Shale. • M - Tanuchitina sp. Koängen core, level 5.55-5.65 m. Lindegård Mudstone. 

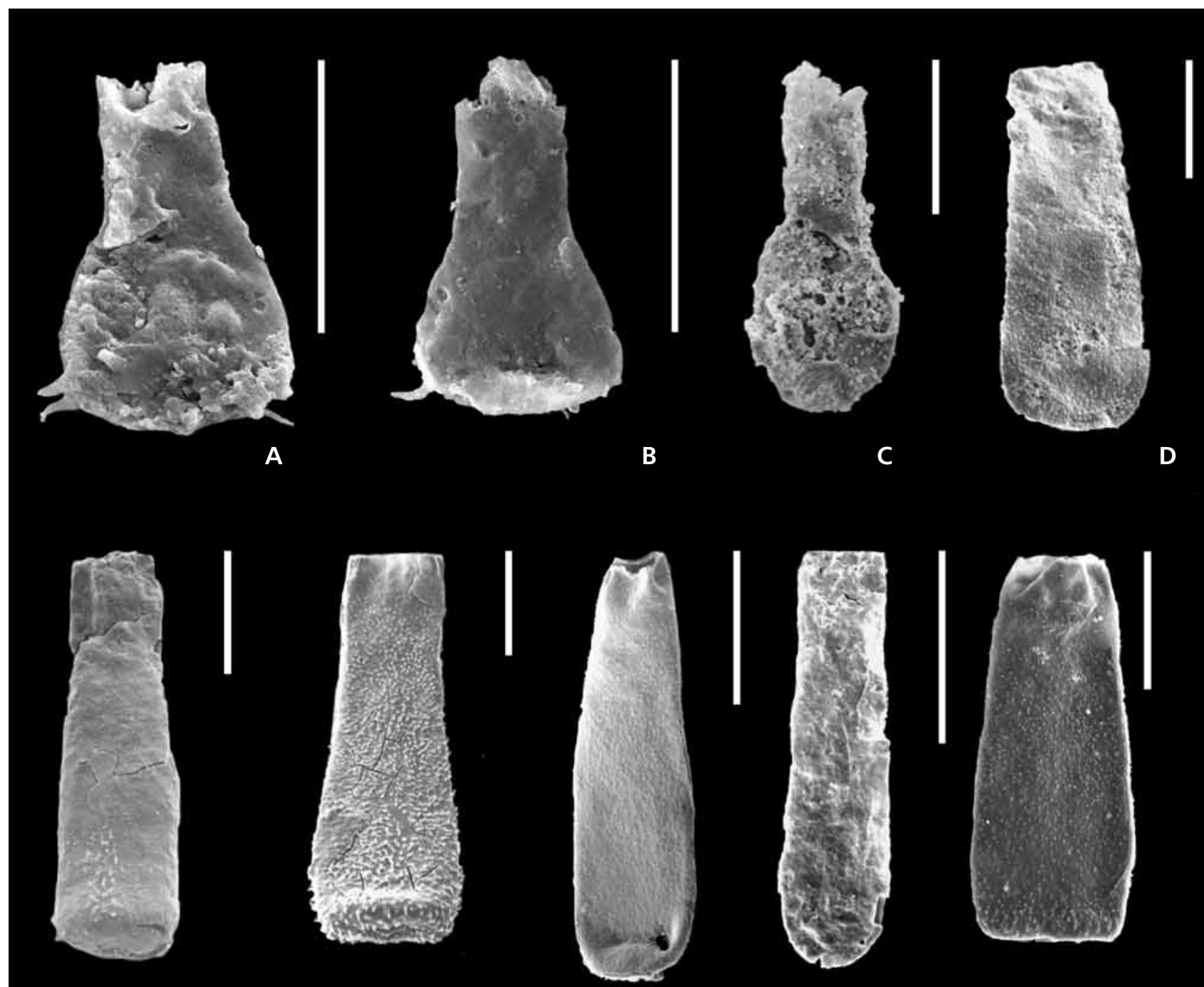

E

F

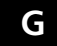

H

I

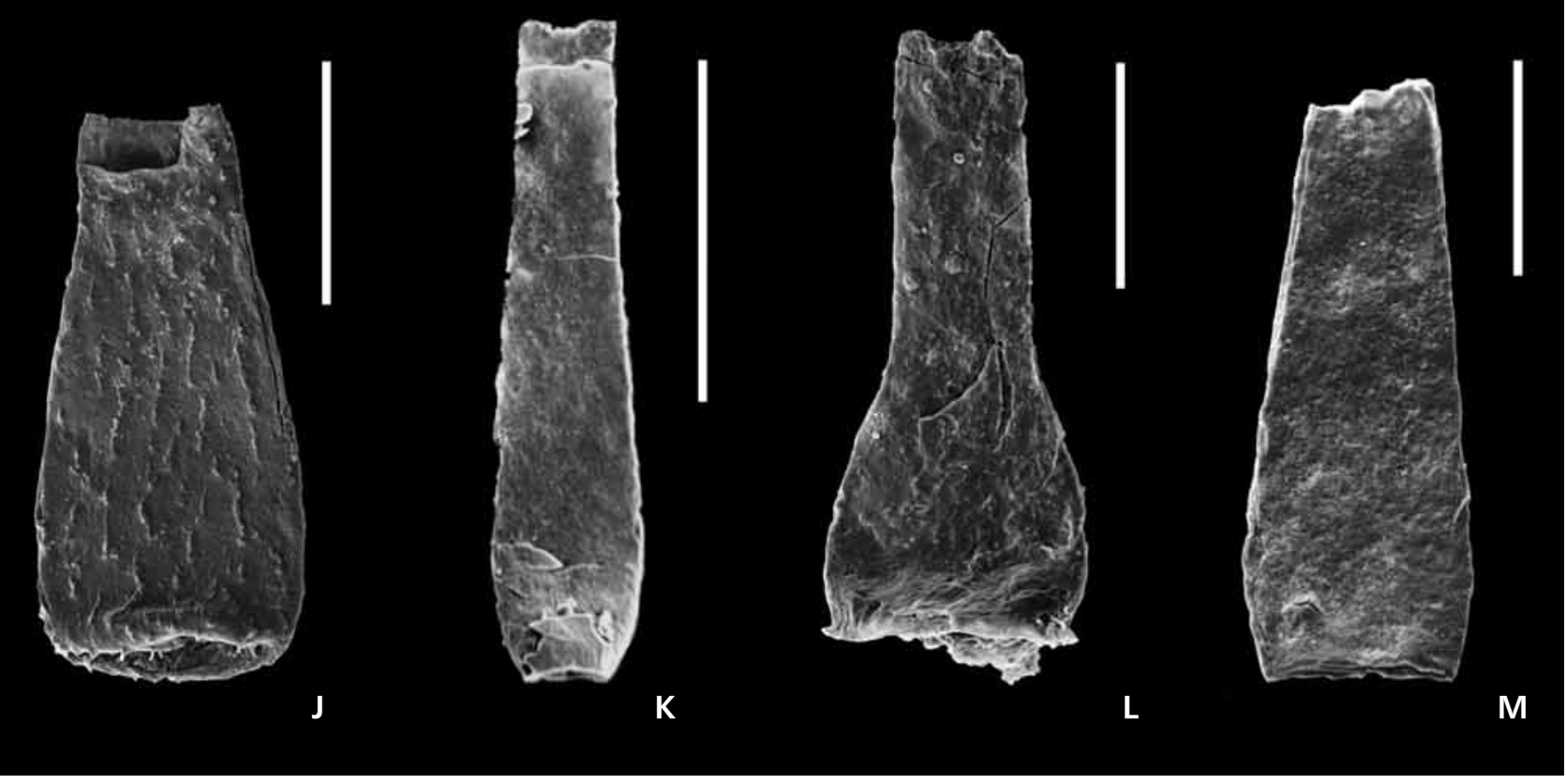


domly distributed simple spines. Flexure distinct. It differs from Angochitina curvata mainly in having simple spines.

Dimensions. - The dimensions given by Vandenbroucke (2004) for his Angochitina curvata?, as well as Lagenochitina dalbyensis are representative for this species.

Remarks. - Specimens illustrated as Angochitina curvata? and Lagenochitina dalbyensis by Vandenbroucke (Plate 1, fig. 15 and Plate 3, figs 12-15 therein) correspond to Angochitina sp. in this study (Fig. 4) and have no similarity to A. curvata and L. dalbyensis. It should also be noted that Armoricochitina granulifera, which precedes $A$. curvata and $L$. dalbyensis in the stratigraphic column, occurs in the correct stratigraphic position (base of D. foliaceous Zone) in the Koängen core (Fig. 4). Furthermore, A. curvata is a very rare species, and the biozone is, in general, only a few $\mathrm{cm}$ thick in Baltoscandia.

Occurrence. - Koängen core (level $67 \mathrm{~m}$ ), lowermost part of the Sularp Formation, Skåne.

Subfamily Ancyrochitininae Paris, 1981

Genus Ancyrochitina Eisenack, 1955

Type species. - Conochitina ancyrea Eisenack, 1931.

\section{Ancyrochitina sp.}

Figure 11A, B

Description. - This small Ancyrochitina species (total length between 116 and $136 \mu \mathrm{m}$ ) is characterized by a short conical body and a short cylindrical neck. Aperture straight. Basal edge rounded and base slightly convex. Flexure distinct. The basal edge has eight short simple appendices (length up to $8 \mu \mathrm{m}$ ). The vesicle wall aperturewards of the appendices is smooth.

Occurrence. - Röstånga core (level 72 m), lowermost part of the Fjäcka Formation, Skåne.

\section{Chitinozoan biostratigraphy}

The Ordovician chrono- and lithostratigraphy of Skåne and Bornholm is summarized in Fig. 10. The chitinozoan biostratigraphy in this study confirms the general outline of the Ordovician chitinozoan biozonation of Baltoscandia (Nõlvak \& Grahn 1993, Nõlvak 1999). Except for strata coeval with the $H$. copiosus Zone (uppermost Tremadocian), the Lower Ordovician part of the Tøyen Formation
(Floian to lowermost Darriwilian, which is roughly equal to Arenig) was not investigated in this study. Noteworthy, is the low diversity of chitinozoan species in graptolitic facies compared to the diversity in carbonate facies of the Central Baltoscandian Confacies Belt. Although the Ordovician chitinozoan zones of Baltoscandia are based on faunas in mostly carbonate facies, it is not difficult to correlate with faunas in the graptolitic facies.

\section{Acknowledgements}

Y.G. thanks Dr. Gunver Krarup Pedersen (Copenhagen University, Copenhagen) for samples from the Billegrav core on Bornholm, and the Swedish Natural Science Council for a grant in 1990 and 1996 (NFR G-GU 8811-303 and G-AA/GU 08811-311) that made his field work possible. The work of J.N. was supported by the Estonian Science Foundation Grant No. 5922. We would like to express our sincere thanks to Prof. Per Ahlberg (Lund University, Lund), Dr. Christina Franzen-Bengtson (Swedish Museum of Natural History, Stockholm), Prof. Maurits Lindström (Stockholm University, Stockholm), Dr. Ulf Sivhed (Geological Survey of Sweden, Lund), and Dr. Arne Thorshøj Nielsen (Geologisk Museum, Copenhagen) for information from literature and maps not easily obtainable in Brazil and Estonia. Prof. Peter Isaacson (Moscow, Idaho) is acknowledged for checking the English.

\section{References}

ACHAB, A. 1989. Ordovician chitinozoan zonation of Quebec and western Newfoundland. Journal of Paleontology 63, $14-24$.

BergströM, J. 1982. Scania. Geological setting. In BRUTON, D.L. \& Williams, S.H. (eds) Field Excursion Guide, IV International Symposium on the Ordovician System. Paleontological Contribution of the University of Oslo 279, 184-197.

Bergström, J., Bergström, S.M. \& LAufeld, S. 1968. En ny skärning genom överkambrium och mellanordovicium i Rävatofta området, Skåne. Geologiska Föreningens i Stockholm Förhandlingar 89, 460-465.

BERGSTRÖM, S.M. 1989. Use of graphic correlation for assessing event-stratigraphic significance and trans-Atlantic relationships of Ordovician K-bentonites. Proceedings of the Academy of Sciences of the Estonian SSR 38, 55-59.

Bergström, S.M., Finney, S.E., Xu, C., PÅlsson, C., Zhi-HaO, W. \& GRAHN, Y. 2000. A proposed global boundary stratotype for the base of the Upper Series of the Ordovician System: The Fågelsång section, Scania, southern Sweden. Episodes 23, 102-109.

Bergström, S.M., Finney, S.C., Xu, C. \& Zhi-haO, W. 1998. The base of the Nemagraptus gracilis Zone as the base of the global Upper Ordovician Series: Three potential stratotypes, 148-151. Sixth International Graptolite Conference and 1998 Field Meeting, IUGS Subcommission on Silurian Stratigraphy, Temas Geologico-Mineros ITGE 23. 
Bergström, S.M., HufF, W.D., Kolata, D.R., Yost, D.A. \& HART, C. 1997. A unique Middle Ordovician K-bentonite bed succession at Röstånga, S. Sweden. GFF 119, 231-244.

Bergström, S.M., Huff, W.D., Koren, T., Larsson, K., AhLBERG, P. \& KolatA, D.R. 1999. The 1997 core drilling through Ordovician and Silurian strata at Röstånga, S. Sweden: Preliminary stratigraphic assessment and regional comparison. GFF 121, 127-135.

Bergström, S.M., Larsson, K., PÅlsson, C. \& Ahlberg, P. 2002. The Almelund Shale, a replacement name for the Upper Didymograptus Shale and the Lower Dicellograptus Shale in the lithostratigraphical classification of the Ordovician succession in Scania, Southern Sweden. Bulletin of the Geological Society of Denmark 49, 41-47.

Bergström, S.M. \& NiLsson, R. 1974. Age and correlation of the Middle Ordovician bentonites on Bornholm. Bulletin of the Geological Society of Denmark 23, 27-48.

Bjerreskov, M. \& Stouge, S. 1985. Field excursion guide, Bornholm, Denmark. Third International conference, Graptolite Working Group 1985. International Paleontological Association, Copenhagen.

Brenchley, P.J., Carden, G.A., Hints, L., Kaljo, D., MarShall, J.D., Martma, T., Meidla, T. \& NõlvaK, J. 2003. High-resolution stable isotope stratigraphy of Upper Ordovician sequences: Constraints on the timing of bioevents and environmental changes associated with mass extinction and glaciation. Geological Society of America Bulletin 115(1), 89-104.

Brenchley, P.J., Marshall, J.D., Hints, L. \& Nõlvak, J. 1997. New isotopic data solving an old biostratigraphic problem: the age of the upper Ordovician brachiopod Holorhynchus giganteus. Journal of the Geological Society, London 154, 335-342.

EISENACK, A. 1931. Neue Mikrofossilien des baltischen Silurs I. Paläontologische Zeitschrift 13, 74-118.

EISENACK, A. 1937. Neue Mikrofossilien des baltischen Silurs IV. Paläontologische Zeitschrift 19, 217-243.

EISENACK, A. 1955. Neue Mikrofossilien aus dem Silur des Baltikums und dem Devon der Eifel. Senckenbergiana Lethaea 36, 311-319.

EISENACK, A. 1959. Neotypen baltischer Silur-Chitinozoen und neue Arten. Neues Jahrbuch für Geologie und Paläontologie, Abhandlungen 108, 1-20.

EISENACK, A. 1962. Mikrofossilien aus dem Ordovizium des Baltikums. 2. Vaginatenkalk bis Lyckholmer Stufe. Senckenbergiana Lethaea 43, 349-366.

EISENACK, A. 1968. Über Chitinozoen des Baltischen Gebietes. Palaeontographica A 131, 137-198.

EisenaCK, A. 1972. Beiträge zur Chitinozoen-Forschung. Palaeontographica A 140, 117-130.

FinNEY, S.C. \& Bergström, S.M. 1986. Biostratigraphy of the Ordovician Nemagraptus gracilis Zone, 47-59. In HugHES, C.P. \& RickARDS, R.B. (eds) Palaeoecology and biostratigraphy of graptolites. Geological Society Special Publication 20.

FUNKQUIST, H.P.A. 1919. Asaphusregionens omfattning i sydöstra Skåne och på Bornholm. Lunds Universitets Arsskrift NF 2(16), 1-56.

GRAHN, Y. 1978. Chitinozoan stratigraphy and palaeoecology at the Ordovician Silurian boundary in Skåne, southernmost Sweden. Sveriges Geologiska Undersökning, Serie C 766, 1-16.

GRAHN, Y. 1980. Early Ordovician Chitinozoa from Öland. Sveriges Geologiska Undersökning, Serie C 775, 1-41.

GRAHN, Y. 1984. Ordovician Chitinozoa from Tallinn, northern Estonia. Review of Palaeobotany and Palynology 43, 5-31.

GRAHN, Y. 1998. Lower Silurian (Llandovery-Middle Wenlock) Chitinozoa and biostratigraphy of the mainland of Sweden. GFF 120, 273-283.

Grahn,Y., IdIL, S. \& Østvedt, A.M. 1994. Caradocian and Ashgillian chitinozoan biostratigraphy of the Oslo-Asker and Ringerike districts, Oslo Region, Norway. GFF 116, 147-160.

Grahn, Y., NõlvaK, J. \& PARIs, F. 1996. Precise chitinozoan dating of Ordovician impact events in Baltoscandia. Journal of Micropalaeontology 15, 21-35.

GRY, H. 1948. Bentoniten i Bornholms ordovicium. Meddeleser fra Dansk Geologisk Forening 11, 364-386.

HADDING, A. 1913. Undre dicellograptusskiffern i Skåne jämte några därmed ekvivalenta bildningar. Lunds Universitets Arsskrift NF 2(9), 1-91.

Hadding, A. 1915a. Der mittlere Dicellograptus-Schiefer auf Bornholm. Lunds Universitets Arsskrift NF 2(11), 1-40.

HADDING, A. 1915b. Undre och mellersta dicellograptusskiffern i Skåne och å Bornholm. Meddeleser fra Dansk Geologisk Forening 4, 361-382.

HEDE, J.E. 1951. Boring through Middle Ordovician-Upper Cambrian strata in the Fågelsång district, Scania (Sweden). 1. Succession encountered in the boring. Lunds Universitets Arsskrift NF 2(46), 1-84.

JAANUSSON, V. 1976. Faunal dynamics in the Middle Ordovician (Viruan) of Balto Scandia, 301-326. In BASSETT, M.G. (ed.) The Ordovician System: Proceedings of a Palaeontological Association Symposium. University of Cardiff Press, Cardiff.

JAANusson, V. 1995. Confacies differentiation and upper Middle Ordovician correlation in the Baltoscandian Basin. Proceedings of the Estonian Academy of Sciences, Geology 44, 73-86.

JANSONIUS, J. 1964. Morphology and classification of some Chitinozoa. Bulletin of Canadian Petroleum Geologists 12, 901-918.

Krarup Pedersen, G. 1989. The sedimentology of Lower Palaeozoic black shales from the shallow wells Skelbro 1 and Billegrav 1, Bornholm, Denmark. Bulletin of the Geological Society of Denmark 37, 151-173.

LAufeld, S. 1967. Caradocian Chitinozoa from Dalarna, Sweden. Geologiska Föreningens i Stockholm Förhandlingar 89, 275-349.

LinDHOLM, K. 1991. Ordovician graptolites from the Early Hunneberg of southern Scandinavia. Palaeontology 34, 283-327.

LinDSTRÖM, A. 1880. Beskrifning till kartbladen Kullen och Höganäs. Sveriges Geologiska Undersökning, Serie Aa 77-78, 1-30.

LindSTRÖM, M. 1953. On the Lower Chasmops Beds in the Fågelsång district (Scania). Geologiska Föreningens $i$ Stockholm Förhandlingar 75, 125-148.

LINDSTRÖM, M. 1955. The conodonts described by A.R. Hadding, 1913. Journal of Paleontology 29, 105-111.

LUNDGREN, B. 1874. Om i Skåne förekommande bildningar, som motsvarar Brachiopodskiffern i Vestergötland. Geologiska Föreningens i Stockholm Förhandlingar 2, 156-159. 
MÅnsson, K. 1995. Trilobites and stratigraphy of the Middle Ordovician Killeröd Formation, Scania, Sweden. GFF 117, 97-106.

Melchin, M. \& Legault, J. 1985. Evolutionary lineages in some Ordovician Chitinozoa. Palynology 9, 199-210.

MoberG, J.C. 1910. Guide for the principal Silurian districts of Scania (with notes on some localities of Mesozoic beds). Geologiska Föreningens i Stockholm Förhandlingar 32, 45-194.

NESTOR, V. 1980. Middle Llandoverian chitinozoans from Estonia. Eesti NSV Teaduste Acadeemia Keemia Geoloogia 29, 136-141.

NiLSSON, R. 1952. Till kännedomen om ordovicium i sydöstra Skåne. Geologiska Föreningens i Stockholm Förhandlingar 73, 682-694.

NiLSSON, R. 1960. A preliminary report on a boring through Middle Ordovician strata in western Scania (Sweden). Geologiska Föreningens i Stockholm Förhandlingar 82, 217-226.

NiLsSON, R. 1977. A boring through Middle and Upper Ordovician strata at Koängen in western Scania, southern Sweden. Sveriges Geologiska Undersökning, Serie C 733, 58 pp.

NiLsSON, R. 1979. A boring through the Ordovician-Silurian boundary in western Scania, south Sweden. Sveriges Geologiska Undersökning, Serie C 766, 1-18.

NõLVAK, J. 1999. Ordovician chitinozoan biozonation of Baltoscandia. Acta Universitatis Carolinae, Geologica 43, 287-290.

NõLVAK, J. 2001. Distribution of chitinozoans, 8-10, App. 8. In PÕLdVERE, A. (ed.) Estonian Geological Sections. Bulletin 3. Valga (10) drill core. Geological Survey of Estonia, Tallinn.

NõLVAK, J. 2003. Distribution of Ordovician chitinozoans, 23-25, App. 22, 23 on CD-R. In PÕLDVERE, A. (ed.) Estonian Geological Sections. Bulletin 5. Ruhnu (500) drill core. Geological Survey of Estonia, Tallinn.

NÕLVAK, J. \& GRAHN, Y. 1993. Ordovician chitinozoan zones from Baltoscandia. Review of Palaeobotany and Palynology 79, 245-269.

OGG, J. 2004. Overview of Global Boundary Stratotype Sections and Points (GSSP's). http://paleopolis.rediris.es/BrachNet/ ANNONCES/ANN/GSSP\%20Boundaries\%20IUGS2004.doc.

OLIN, E. 1906. Om de chasmopskalken och trinucleusskiffern motsvarande bildningarne i Skåne. Lunds Universitets Arsskrift NF 2(3), 1-79.

PÅLsSON, C. 1996. Middle-Upper Ordovician trilobites and stratigraphy along the Kyrkbäcken rivulet in the Röstånga area, southern Sweden. GFF 118, 151-162.

PARIS, F. 1981. Les Chitinozoaires dans le Paléozoïque du sud-ouest de l'Europe (cadre géologique - étude systématique - biostratigraphie). Mémoire de la Société géologique et mineralogique de Bretagne 26, 1-492.

Paris, F., Grahn, Y., Nestor, V. \& Lakova, I. 1999. Proposal for a revised chitinozoan classification. Journal of Paleontology $73,549-570$.

PoulsEN, C. \& POUlSEN, V. 1979. Lag fra Jordens oldtid, 51-82. In NøRREVANG, A. \& Lundø, J. (eds) Danmarks Natur 1. Landskabernas opståen. $3^{\text {rd }}$ edition. Politikens Forlag, København.

REGNÉLL, G. 1955. Leiosphaera (Hystricosph.) aus unterordovizischen Kalkstein in SO-Schonen, Schweden. Geologiska Föreningens i Stockholm Förhandlingar 77, 546-556.

REgnélL, G. 1960. The Lower Palaeozoic of Scania. In REGNÉLL, G. \& HEDE, J.E. The Lower Palaeozoic of Scania. The Silurian of Gotland. International Geological Congress, XXI Session, Norden 1960, Guidebook Sweden d, 3-43.

SCHALlReUTER, R. 1963. Neue Chitinozoen aus ordovizischen Geschieben und Bemerkungen zur Gattung Illichitina. Paläontologische Abhandlungen 1, 391-405.

SCHALlReUter, R. 1981. Chitinozoen aus dem Sularpschiefer (Mittelordoviz) von Schonen (Schweden). Palaeontographica B 178, 89-142.

SCHALLREUTER, R. 1983. Sularpschiefer (Mittelordoviz) als Geschiebe in Norddeutschland. Mitteilungen aus dem Geologisch-Paläontologischen Institut Universität Hamburg 54, $55-64$.

Soufiane, A. \& ACHAB, A. 2000. Upper Ordovician and Lower Silurian chitinozoans from central Nevada and Arctic Canada. Review of Palaeobotany and Palynology 113, 165-187.

StAufFer, C.R. 1933. Middle Ordovician Polychaeta from Minnesota. Bulletin of the Geological Society of America 44, 1173-1218.

TJERNVIK, T. 1958. Tremadocian beds at Flagabro in South-Eastern Scania (Sweden). Geologiska Föreningens i Stockholm Förhandlingar 80, 259-276.

TÖRNQUIST, S.L. 1875. Berättelse om en geologisk resa genom Skånes och Östergötlands paleozoiska trakter, sommaren 1875. Öfvers Kungliga Vetenskapsakademins Förhandlingar 1875(10), 42-70.

Troedsson, G.T. 1918. Om Skånes brachiopodskiffer. Lunds Universitets Arsskrift NF 2(15), 1-104.

Troedsson, G.T. 1920. Skånes dalmanitesskiffer, en strandbildning. Geologiska Föreningens $i$ Stockholm Förhandlingar 42, 265-290.

TROEDSSON, G.T. 1932. Några tektoniska och stratigrafiska problem i Skåne. Geologiska Föreningens $i$ Stockholm Förhandlingar 54, 220-226.

TUlLbERG, S.A. 1880. Om lagerföljden i de kambriska och siluriska aflagringarne vid Röstånga. Geologiska Föreningens i Stockholm Förhandlingar 5, 86-101.

VANDENBROUCKE, T. 2004. Chitinozoan biostratigraphy of the Upper Ordovician Fågelsång GSSP, Scania, southern Sweden. Review of Palaeobotany and Palynology 130, 217-239. 